\title{
Imigrantes italianos no núcleo colonial de São Caetano do Sul
}

\author{
ELIANE MIMESSE*
}

Resumo: Este artigo trata da história do núcleo colonial de São Caetano e dos imigrantes italianos. Resgatou-se os antecedentes da colonização das terras, até estas tornarem-se um núcleo colonial. Possibilita-se desta forma uma melhor compreensão das dificuldades de sobrevivência. A persistência destes colonos consolidou-se com o progresso da localidade.

Abstract: This study is about the colonial nuclear of São Caetano city and its Italian immigrants. The antecedents of the land colonization is explored until the colonial nuclear is formed. The difficulties of surviving is better understood in this way. The persistence of the colonial residents become consolidate with the local progress.

Palavras-chave: Italianos. Núcleo colonial.

Key words: Italians. Colonial nuclear.

\section{Da colonização a formação do núcleo}

As terras da atual cidade de São Caetano do Sul, localizada na região Sudeste do estado de São Paulo, eram habitadas por índios até meados do século XVI, e denominadas terras de Tijucuçu. Em 1596 chegaram Diogo Sanches e Isabel Félix que receberam uma sesmaria, ${ }^{1}$ construíram a sua moradia e trabalharam a terra para o plantio, permaneceram poucos anos na propriedade. Em 1601 terras próximas a esta foram herdadas por Duarte Machado. Este proprietário era bandeirante e manteve na localidade por muito tempo uma fazenda para

\footnotetext{
* Mestre em Educação pela PUC-SP.

${ }^{1}$ Lote de terra cedido pelo governo ao sesmeiro para cultivo. As capitanias hereditárias eram formadas por várias sesmarias.
}

Estudos Ibero-Americanos. PUCRS, v. XXVI, nº 1, p. 163-182, julho 2000. 
a criação de gado. Doou as terras, de acordo com seu testamento para a Ordem de São Bento, no ano de 1631.

Outra sesmaria nas mesmas terras chamadas de Tijucuçu pertenceu ao capitão Manoel Temudo. Quando de sua morte foi levada a leilão para pagamento de suas dívidas e, em 1671, adquirida pelo bandeirante Fernão Dias Paes. Este último comprou as terras para doar aos monges. Com as terras doadas por Duarte Machado e por Fernão Dias Paes, mais algumas terras compradas, foi possível à Ordem compor a Fazenda do Tijucuçu. (Martins,1991, p.4-17)

O espaço ocupado por estas sesmarias era muito maior do que o traçado atual da cidade. Estendia-se por uma parte dos atuais bairros vizinhos da cidade de São Paulo e da cidade de São Bernardo do Campo. As redefinições dos limites foram elaboradas de acordo com as vendas das partes das terras, mudanças da população, as cheias dos rios, a construção e posterior duplicação da estrada de ferro.

As doações e as novas aquisições de terras possibilitaram a ocupação do local pelos religiosos. Alguns escravos indígenas acompanharam-nos. Aos poucos a fazenda foi transformada em centro produtor de tijolos, além das plantações para a subsistência de gêneros como a mandioca, o arroz, o feijão, o milho e o amendoim para fazer azeite. Criavam-se gado e pequenos animais e chegou-se a comercializar a carne destes animais em outras localidades. (Piratininga Júnior, 1991, p.53)

Entre os anos de 1717 e 1720 foi construída a Capela de São Caetano, próxima a casa-grande e a algumas pequenas casas feitas para a moradia dos escravos. Em 1730 a denominação do lugar mudou para Fazenda de São Caetano do Tijucuçu, fato que ocorreu após o término da construção da capela, que recebeu a imagem do santo. Em 1743 o nome foi novamente mudado para Fazenda de São Caetano.

Desde a construção do primeiro forno e da olaria, em meados de 1730, a fazenda havia prosperado com a produção de telhas, tijolos, lajotas, ladrilhos e louças para uso doméstico, chegando a abastecer os moradores da vila de São Paulo. O número de escravos aumentou com o tempo. Os administrados eram normalmente doados por fiéis em troca de missas para suas almas. (Martins, 1988, p.11). Os africanos eram provenientes de outras fazendas da congregação. As proibições com relação a escravidão indígena e a mudança gradual da atividade econômica da fazenda, levaram os administrados a cuidarem do gado e os africanos da olaria. Desta forma, os indígenas foram gradual- 
mente substituídos pelos africanos, como a criação de gado pela produção de tijolos.

A concorrência na produção de tijolos fez os monges diminuírem os preços de suas mercadorias, acarretando mudanças na organização do trabalho e na disposição dos escravos, que deveriam trabalhar mais nos fornos e dedicar-se menos as suas plantações individuais. Estas e outras questões levaram os monges a libertarem os escravos em setembro de 1871 e abandonarem as terras.

O governo enviou para a área engenheiros a fim de analisar as possibilidades desta tornar-se uma colônia agrícola. ${ }^{2} \mathrm{O}$ parecer técnico de setembro de 1874 recomendava ao governo a compra da fazenda. (Martins, 1992,p.52). Foi efetuada a compra e o processo de desapropriação da Fazenda de São Caetano teve início em setembro de 1876. Neste local foi criado o núcleo colonial.

\section{Os imigrantes no núcleo colonial}

Os núcleos visavam a colonização de terras por imigrantes. A princípio localizavam-se distantes dos centros produtores de café. A possibilidade de aquisição de terras em forma de pequenas propriedades atraiu para o Brasil um grande número de pessoas, ainda mais pelas subvenções em dinheiro oferecidas pelo governo. $\mathrm{O}$ intuito dos grandes proprietários de terras era usar a mão-de-obra destes imigrantes para trabalhar nas fazendas.

O que os fazendeiros precisavam mesmo era de trabalhadores que atendessem as necessidades crescentes de mãode-obra, estranguladas pela baixa reprodução demográfica do escravo e pela crise do comércio negreiro derivada da cessação do tráfico. A política de colonização, baseada na pequena lavoura, numa espécie de neo-campesinato implantado pelo próprio capital e pela grande lavoura, constituía uma concessão necessária dos grandes fazendeiros às presumíveis aspirações dos emigrantes potenciais dos países que tinham, então, um excesso relativo de mão-deobra rural. (Martins, 1978, p.X)

${ }^{2}$ Decreto 3784 de $19 /$ janeiro/1867. Artigo $1^{\circ}$ - As colonias do Estado serão creadas por Decreto do Governo Imperial, com designação do respectivo nome e districto . colonial previamente escolhido, medido e demarcado por engenheiro do Governo. 
A legislação brasileira estabeleceu o tipo de imigrante que lhe interessava para ingressar no país: exigia um certificado de boa conduta, proibia o embarque de menores de 12 anos sem acompanhantes, de pessoas idosas, de indivíduos com algum tipo de deficiência e estava atento para a proporção de homens e mulheres solteiros. (Carneiro, 1950, p.30-34)

A Itália foi um país fornecedor de mão-de-obra barata em fins do século XIX, por suas condições sócio-políticas e econômicas. Os nortistas, vindo da região do Vêneto, a princípio instalaram-se nos núcleos coloniais como o de São Caetano, eles haviam abandonado suas terras porque, com

a integração do Vêneto ao mercado nacional recémunificado (1870), as bases de sustentação dessa economia camponesa começaram a ruir. Entre as possíveis causas da proletarização desses pequenos proprietários, que foram obrigados a se ocupar ocasionalmente de outros afazeres para completar o orçamento doméstico, pode-se incluir: a tradição de dividir a terra quando os filhos se casavam; a ausência de melhorias técnicas na agricultura; a pesada carga tributária que sobre eles caía; a alteração ecológica com a devastação das florestas e com a conseqüente diminuição das chuvas. Há que se ter em conta também a explosão demográfica na zona rural. (Alvim, 1986, p.31)

Quando saíram do seu país não tinham a pretensão de voltar, desfaziam-se de todos os seus bens e de sua pequena propriedade que "lhes dava uma ilusão de independência", o que não ocorria mais nestes anos. Todos aceitavam os contratos de trabalho impostos e os locais para onde deveriam ir quando chegassem ao Brasil; a imigração surgiu como solução para a sobrevivência.

Os imigrantes de São Caetano vieram da região de VitórioVêneto no Nordeste da Itália, embarcaram em 1877 no vapor Europa na cidade portuária de Gênova e desembarcaram em Santos. Vieram de trem para a Hospedaria dos Imigrantes na cidade de São Paulo, local onde todos os imigrantes se dirigiam quando chegavam ao país, permanecendo lá por oito dias.

Traziam um prospetto contendo as condições mínimas para o imigrante que tivesse pretensões de fixar-se em um núcleo, no estado de São Paulo, na localidade que o governo tivesse lotes disponíveis. 
Seria possível escolher entre três tipos de lotes, com preços diferentes de acordo com a extensão, além das formas de pagamento:

\begin{abstract}
Cada agricultor que se estabelecer em uma Colônia do Estado, terá direito a um lote de terra. Estes lotes dividem-se em três classes: a $1^{\text {a }}$ é de 125.000 braças quadradas, tendo 605.000 metros quadrados, a $2^{\mathrm{a}}$ é de 62.500 braças quadradas e 302.500 metros quadrados, e a $3^{\text {a }}$ é de 31.250 braças quadradas e 151.350 metros quadrados, valendo a um preço que será fixado pelo Diretor da Colônia, e que poderá variar de 2 a 8 réis cada braça quadrada, ou seja, o metro quadrado 4,84. (...) o pagamento será feito em cinco parcelas, começando do fim do segundo ano da posse do colono. ${ }^{3}$
\end{abstract}

Os colonos que conseguissem quitar o lote antes do prazo, teriam um desconto. Mas isso não ocorreu na colônia estudada. ${ }^{4}$

Depois da parada obrigatória na Hospedaria, os italianos rumaram para São Caetano, de trem. A ferrovia construída pelos ingleses havia sido inaugurada em fevereiro de 1867, com algumas paradas nos locais considerados mais importantes. A estrada de ferro, que ligava as cidades de Santos a de Jundiaí, foi a primeira a ser construída no estado de São Paulo e a sua inauguração havia sido entusiasticamente anunciada:

3 "Ogni agricoltore che si stabilirà in una Colonia dello Stato, ha diritto ad un lotto di terreno. Questi lotti si dividono in tre classi:

La $1^{\circ}$ è di 125.000 braccia quadrate, ovvero 605.000 metri quadradi

$\begin{array}{lllll}\text { La } 2^{\circ} \text { è di } 62.500 & " & " & \text { " } & 302.500 \\ \text { La } 3^{\circ} \text { è di } 31.250 & " & \text { " } & 151.350\end{array}$

valutati ad un prezzo che sarà fissato dal Direttore della Colonia, e che potrà variare da 2 a 8 reis ogni braccio quadrato, ossia metri quadrati 4,84 . (...) il pagamento sarà fatto in cinque rate, a cominciare dalla fine del secondo anno di possesso del colono." (Emigrazione al Brasile, vantaggi offerti agli emigranti. Fundação PróMemória de São Caetano do Sul. 1877.).

${ }^{4}$ Outras informações sobre as condições para a aquisição dos lotes rústicos ou urbanos, suas metragens, formas de pagamento a prazo, títulos definitivos e provisórios constam detalhadamente do Decreto 3784 de 19/janeiro/1867, capítulo I - Fundação das colonias, distribuição de terras e condições de propriedade. 
ia ser brevemente realidade a obra d'esse extraordinario engenho que, por onde quer que passe, vai projectando um feixe brilhante de luz e deixando um rastro fecundo de civilização. (Pinto, 1977, p.35)

Em São Caetano ainda não existia uma estação para o desembarque das pessoas, obrigando os imigrantes a saltarem do trem com suas bagagens. No depoimento de Dona Esperança Martorelli Cairo existem lembranças contadas por sua avó sobre o dia da chegada no porto de Santos:

Quando eles chegaram em Santos, desceram do navio, então o governo daqui levou muitos negros para descarregar a bagagem deles do navio. Foi quando eles viram pela primeira vez gente negra, eles nem sabiam que existia, minha avó falou. Justo muitos desses aí vieram no trem com eles, aí eles desceram no Brás naquele dia, mas a bagagem ficou dentro do trem, no dia seguinte aí veio o maquinista e levou eles para o lugar onde eles tinham que ir. Quando eles chegaram aí no rio dos Meninos, naquele lugar que desceram eles viram que não tinha nem estação, não tinha nada (...) nas bagagens eles trouxeram muita pá, picareta, espingarda, eles trouxeram tudo que puderam da Itália. ${ }^{5}$

A extensão de terras da antiga fazenda era ideal para abrigar os recém-chegados, por estar próxima da Capital, ser local de passagem dos trens, além de contar com rios e terras férteis para o plantio e, ainda, pastagens para a criação de animais. Havia também as construções que permaneceram nas terras, que serviriam de abrigo para as pessoas antes de construírem suas casas, já que, de acordo com a legislação, as colônias deveriam ter um edifício especial para receber os imigrantes até a construção de suas casas. ${ }^{6}$ Neste caso a construção de um prédio não foi necessário, a antiga casa-grande dos beneditinos foi suficiente para acomodar todas as pessoas.

${ }^{5}$ Projeto História de Vida. Fundação Pró-Memória de São Caetano do Sul. 1995.

${ }^{6}$ Decreto 3.784 de 19/janeiro/1867, capítulo III - Recepção e estabelecimento de colonos. 
Mas, as condições de vida dos colonos foi extremamente precária quando de sua chegada, em 28 de julho de 1877. As 28 famílias $^{7}$ encontraram as ruínas das construções da antiga fazenda composta pela casa-grande, a capela e as 12 casas das antigas senzalas. Além disso, moravam no local quatro famílias de brasileiros, três formadas por ex-escravos dos beneditinos e uma família de alemães. Tudo estava por fazer: as casas, as plantações, as divisões dos lotes, etc.

Os representantes do governo provincial, mantiveram um escritório da Inspetoria de Terras e Colonização ${ }^{8}$ neste mesmo espaço. A legislação das colônias do Estado determinava a criação de uma junta, para viabilizar a tutela, composta por oito membros: o diretor do núcleo, um médico e seis colonos. Os colonos que quitassem suas dívidas poderiam compor o grupo. $\mathrm{Na}$ impossibilidade de participação de todos os componentes, a junta funcionaria somente com o diretor. ${ }^{9}$

Neste período muitos faleceram, principalmente crianças, devido a febre tifóide o que gerou outros problemas, como o da falta de um cemitério na colônia e de um pároco para encomendar os mortos. A solução foi o comparecimento de um padre quinzenalmente na localidade para celebrar missas, batizar crianças e rezar pelos falecidos. Mas os mortos ainda não tinham um cemitério. Eram enterrados no de São Bernardo, até que o pároco local não os aceitou mais, desta maneira, eram então encaminhados ao cemitério da Consolação em São Paulo entre 1878 e 1893; a partir deste ano passaram a ser sepultados no recém inaugurado Cemitério Municipal do Brás, também na Capital, até a construção do cemitério local no ano de 1911.

O regime de tutela dos imigrantes previa algumas funções a serem cumpridas pelo governo imperial, representado na colônia pelo escritório da Inspetoria: ceder gêneros alimentícios, antecipar os ins-

${ }^{7}$ Eram formadas pelos seguintes nomes: Antonio Daffré, Antonio Gallo, Antonio Garbelotto, Antonio Martorelli, Celeste De Nardi, Celeste Pantallo, Domenico Bottan, Domenico Perin, Eliseo Leone, Francesco Bortolini, Francesco De Martini, Francesco Fiorot, Gaetano Garbelotto, Gartano Garbelotto Filho, Giacomo Dal Cin, Giacomo Garbelotto, Giovanni De Nardi, Giovanni Moret, Giovanni Peruch, Giovanni Tomé, Giuseppe Braido, Giuseppe De Savi, Luigi D'Agostini, Modesto Castelotti, Natale Furlan, Paolo Martorelli, Pietro Pessot e Tommaso Tomé.

${ }^{8}$ A Inspetoria Geral de Terras e Colonização foi criada em 1876 pelo governo imperial. Tinha como função promover e organizar todos os serviços relacionados a imigração.

${ }^{9}$ Decreto 3.784 de 19/janeiro/1867, capítulo II - Administração das Colonias. 
trumentos agrícolas, contribuir na demarcação dos lotes, ajudar nos enterros e nas missas, providenciar padres e médicos. A legislação também previa o sustento dos colonos até o seu estabelecimento no lote adquirido, e eles deveriam receber um auxílio em dinheiro e as sementes necessárias para as primeiras plantações assim que tomassem posse. Mesmo com a legislação em vigor, os entraves entre o governo e os colonos persistiram e nem sempre as leis eram cumpridas. Os colonos ficaram morando nas casas precárias sem terem seus lotes distribuídos até janeiro de 1878. Neste mês os primeiros colonos começaram a receber as suas terras. A distribuição teve início no primeiro dia do mês de janeiro, tudo com muita morosidade. Os alimentos e as sementes para o plantio não eram fornecidos com freqüência e as diárias pelo trabalho realizado nos lotes não eram pagas. Esta situação gerou duas manifestações de descontentamento, na primeira o diretor do núcleo colonial chegou a ser aprisionado, para forçar o comparecimento das autoridades. Compareceram o presidente da Câmara Municipal de São Paulo e o chefe de polícia. (Martins, 1992, p. 38). Mas nada foi facilmente solucionado e os italianos continuaram trabalhando sem receber.

A tutela do governo durava em média dois anos, até que fosse efetuada a primeira colheita - esse era um dos pontos do contrato entre imigrantes e governo. Outros eram o transporte do país de origem até a colônia, além das despesas iniciais como o fornecimento de instrumentos e sementes para o plantio. Na colônia de São Caetano, a tutela terminou em 3 de junho de 1879, quando as famílias que permaneceram nas terras conseguiram estabelecer-se em seus lotes. Os funcionários do escritório ainda permaneceram na colônia por alguns meses depois do término do prazo.

Neste momento os colonos já haviam aberto as valas que delimitavam os lotes, plantavam cereais, comercializavam carvão e cultivavam uva. Com estas atividades conseguiam o suficiente para a sobrevivência e até a venda de algumas mercadorias. O carvão era o mais lucrativo: a lenha era retirada da mata gratuitamente, para em seguida ser queimada e vendida em São Paulo.

Nem todas as famílias que chegaram em julho de 1877 permaneceram em São Caetano. Muitos mudaram para as colônias do Sul do país, na região do atual estado do Rio Grande do Sul, outros foram para a Argentina e outros voltaram para a Itália. No recenseamento de abril de 1878, constam em São Caetano 172 pessoas, de um total de 251 que chegaram em julho de 1877. 
No ano da desvinculação da colônia com o governo imperial, 1879, o bispo de São Paulo, Dom Lino Deodato Rodrigues Carvalho, aprovou um pedido dos imigrantes para a criação de uma irmandade religiosa na localidade. O bispo firmou um compromisso com estas pessoas e a Irmandade de São Caetano foi criada para

a adoração do Santíssimo Sacramento e ao culto do padroeiro da Capela local. Seus membros, homens e mulheres, deviam comparecer aos atos religiosos revestidos da opa vermelha. Seu calendário era um calendário religioso, que coincidia com o calendário agrícola, regulado pela festa de São Caetano, a 7 de agosto de cada ano. (...) O pároco do Brás era membro nato da Irmandade. (...) As jóias eram contribuições dos membros da Irmandade: os fundadores deviam pagar Rs. $1 \$ 000$ e os demais, alistados depois deles, deviam pagar Rs. $1 \$ 500$ de entrada e uma contribuição anual de Rs. $1 \$ 000$. (...) Suas atividades, não se reduziam às do culto, mas se estendiam a aspectos da vida civil. Além do caixão comunitário e do sepultamento dos mortos. (Martins, 1992, p.182)

Deste modo, algumas ações do então extinto escritório da Inspetoria de Terras e Colonização foram assumidas pelos colonos, como a realização das missas mensais - que não ocorriam realmente com esta freqüência - e a organização dos enterros. A Irmandade também cuidava da cooperação mútua e da troca de informações sobre as formas de plantio e de como trabalhar a terra com gêneros diferentes de alimentos.

Em 1882, a Irmandade conseguiu licença para celebrar uma missa anual no dia sete de agosto, acompanhada de uma festa em homenagem ao santo protetor da localidade. Esta licença foi necessária para o comparecimento, imprescindível, do pároco no dia indicado. Foi o início da "Festa de São Caetano", a partir do ano de 1883.

A festa foi noticiada no jornal várias vezes. A sua importância foi reiterada como homenagem ao santo e como motivo de encontro das pessoas. Muitos moradores de São Paulo mantinham relações comerciais com as pessoas da colônia e a estrada de ferro facilitava o transporte dos passageiros à festividade. A Irmandade organizou a 
festa por muitos anos e conseguiu suprir as necessidades da comunidade naquele momento.

Segundo os depoimentos dos antigos moradores, ${ }^{10}$ esta foi uma época difícil. Plantavam alimentos para a sobrevivência como mandioca, batata e também salsa, alho e uva. Com o dinheiro da venda de seus produtos, compravam em São Paulo a farinha para fazer o pão e as massas. A venda do carvão e dos ovos ou das pequenas criações de galinhas e pombos ajudava a aumentar a renda. Com o tempo, a caça foi ficando rara, pois o desmatamento para o fabrico do carvão contribuía com o deslocamento dos animais. A pesca também era fonte de alimento. À medida que ocorreram aquisições de animais maiores como vacas leiteiras e mulas para o transporte, a vida foi tornando-se mais fácil e as entregas do carvão ficaram mais rápidas.

Até o ano de 1879 mais 15 famílias chegaram à localidade; outras já haviam desistido de seus lotes. Foi uma nova tentativa de revitalizar a colonização, redistribuindo os lotes vagos. Aumentaram as dificuldades diárias, mais pessoas cortavam lenha para fazer o carvão e vendê-lo, acirrando a concorrência. A necessidade gerou novas atividades, como a narrada pela Dona Joana Fiorotti Zanini, que fala sobre seus pais:

minha mãe foi ama-de-leite na época que morreu um filho seu, sei que tinha muito leite, e naquele tempo os ricos não amamentavam os filhos, tinham uma ama em casa, minha mãe, então, foi amamentar uma neta da Baronesa em São Paulo. Imagine que lá nesta casa, se um frango não estivesse bem cozido ou alguma coisa que as cozinheiras fizessem de errado, eles davam a comida para o meu pai, porque ele ia vender carvão nessa casa. Eles davam os pratos já prontos, cozidos, para o meu pai levar para casa. ${ }^{11}$

A escassez inevitável do carvão fez com que os colonos fossem comprá-lo em outras terras, para depois revendê-lo.

No início dos anos 80 , os três fornos dos antigos proprietários beneditinos ainda permaneciam em condições de uso e passaram a ser aproveitados pelos colonos para fazer tijolos. Eles fundaram a primei-

\footnotetext{
${ }^{10}$ Projeto História de Vida. Fundação Pró-Memória de São Caetano do Sul. 1995.

${ }^{11}$ Idem, ibidem.
} 
ra olaria e, assim, reconstruíram e ampliaram suas casas, que até este momento eram de madeira.

No ano de 1880 parte do local destes fornos foi adquirido por Samuel Eduardo da Costa Mesquita, que aumentou a produção e vendeu tijolos até para a Capital. Algumas das olarias dos colonos, estabelecidas às margens do rio dos Meninos, também contribuíram com as construções na Capital.

Do ano da criação do núcleo, 1877, até o início dos anos 80, ou melhor, o dia $1^{\circ}$ de maio de 1883 , data da inauguração da estação de trem, a comunicação e o deslocamento das pessoas eram feitos principalmente pelas trilhas na mata, a pé, a cavalo, de carroça, ou de barco pelo rio Tamanduateí. Como já foi dito, não existia a estação, os moradores recorriam a certos sinais para pegar o trem. No depoimento de Dona Esperança Martorelli Cairo as recordações recaem sobre as bandeirinhas balançando no ponto mais alto da igreja, que ainda era uma pequena capela barroca.

(...) fez uma porção de bandeirinhas vermelhas e pôs na capela, quem ia pegar o trem, pegava uma bandeirinha daquela vermelha e colocava lá, aí então o maquinista via que tinha uma bandeirinha vermelha então ele parava, sabia que tinha gente para subir, a bandeirinha ficava lá até eles voltarem, quando voltavam de São Paulo aí eles tiravam a bandeirinha e o trem não parava mais lá. ${ }^{12}$

As bandeiras eram colocadas na igreja e, quando avistadas pelo maquinista, ele reduzia a velocidade e efetuava o embarque das pessoas, muitas vezes com a composição em movimento. Por estes e outros transtornos a estação de trem foi construída, em um local mais distante da igreja e mais alto, porque quando chovia muito a enchente não permitia a parada do trem ou até mesmo sua passagem. Paravam diariamente na estação dois trens, um pela manhã em direção a Santos e outro à tarde em direção a São Paulo. Durante a festa de São Caetano, em agosto, mais dois trens faziam a parada na colônia, como se pode ver numa notícia do jornal:

${ }^{12}$ Idem, ibidem. 


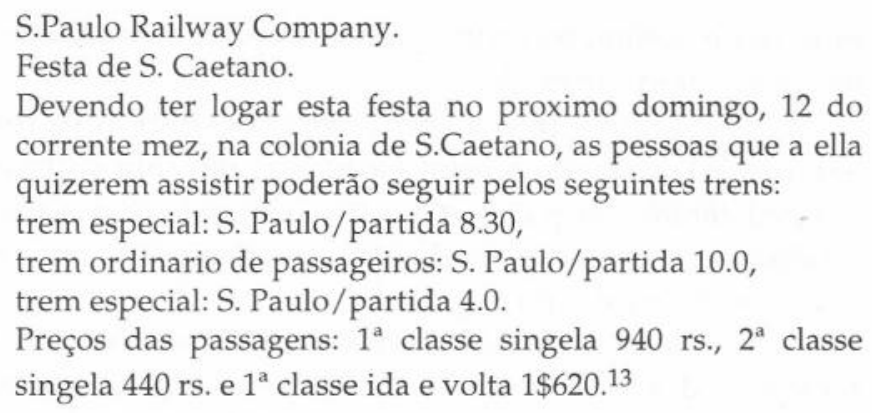

Por esta época os colonos criavam porcos e galinhas, plantavam cevada, linho, batata, feijão, milho, fumo, arroz e uva. Esta última foi um avanço para a colônia, que chegou a vender seu vinho na Capital e até fazer propagandas no jornal. Foi o cultivo das vinhas o incentivo necessário para a Fábrica de Bebidas Alcóolicas e Refinação de Açúcar criada em 1882.

Nestes anos a mão-de-obra dos colonos contribuiu com a construção do Museu Paulista do Ipiranga. As obras tiveram início em 1885 e foram consideradas concluídas em 1890. Os pedreiros, pintores, marceneiros, carpinteiros e outros profissionais foram recrutados entre os italianos, que moravam em São Paulo. (Cenni, 1975, p.328). O arquiteto responsável era italiano e julgava que seus conterrâneos tinham mais habilidades do que os brasileiros para construir este tipo de palácio. De fato, o depoimento de Dona Joana Fiorotti Zanini ${ }^{14}$ trata da participação do pai e do tio, como pedreiros na construção do $\mathrm{Mu}$ seu. Os dois iam a pé de madrugada para São Paulo, porque o trem só passava neste sentido no final da tarde. Os mais velhos ficavam na colônia cuidando das plantações, apenas os mais novos procuravam outros afazeres.

No ano de 1887, foi feita uma nova distribuição das terras da colônia, ${ }^{15}$ sendo os lotes divididos em urbanos e rurais: eram as terras que foram abandonadas ou que ainda não tinham proprietários. A nova distribuição dos lotes seria uma forma de povoar o núcleo e também de evitar que os colonos continuassem morando nas antigas

\footnotetext{
${ }_{13}$ A Provincia de São Paulo, 11/ agosto/1883.

14 Projeto História de Vida. Fundação Pró-Memória de São Caetano do Sul. 1995.

15 Desde 1884, as famílias de imigrantes que se instalassem nas fazendas ou em núcleos coloniais da província de São Paulo não precisariam mais arcar com os gastos de transporte: o governo, a partir deste momento, pagaria as passagens. (Trento, 1989, p. 23).
} 
casas da senzala, apenas explorando a terra sem a preocupação de fixar-se e construírem suas casas.

Com a chegada de novos colonos e com a instalação da estação de trem, as relações de convívio entre as pessoas na localidade diversificaram-se, tornando-se, por vezes, conflituosas. Em 1888 houve um incidente entre os italianos, que estavam na igreja, e os brasileiros que trabalhavam na Fábrica de Tijolos Paulista. O proprietário da fábrica, Samuel Eduardo da Costa Mesquita, havia adquirido algumas das terras próximas da igreja e, com o tempo, outras, que, de acordo com o traçado original do núcleo, estavam reservadas para a ampliação da igreja e a construção do cemitério. A proximidade entre o local de orações e a fábrica, construída no local considerado pelos italianos como sagrado, gerou este e outros conflitos posteriores.

Outra versão sobre este incidente é do depoimento de Dona Esperança Martorelli Cairo. O avô da entrevistada, Antônio Martorelli participou da confusão:

Aí o pessoal brigaram dentro da capela, não queriam que meu avô e o Moretti se juntasse com esse português. Não queriam (...) e fizeram uma briga dentro da capela e eu não sei quem é, que estava armado e deu um tiro lá, eu sei que meu avô apanhou, saiu machucado. ${ }^{16}$

A discussão teria começado logo depois da reza, ainda dentro da igreja, quando alguns moradores disseram pretender trabalhar com o brasileiro. Deixariam as suas plantações para os filhos e aprenderiam as novas técnicas usadas na fábrica para a produção de tijolos. Este é o momento em que o carvão não era mais tão lucrativo como no início. Pela necessidade da mudança das atividades comerciais, dois colonos se dispuseram a trabalhar com o brasileiro para aprender o ofício, para depois montarem as suas próprias olarias.

Como a saída dos trabalhadores da fábrica ocorria na mesma hora da reza, ao entardecer, todos encontraram-se na saída, uns da reza e outros da fábrica. Os italianos continuaram a discussão e envolveram os brasileiros. Os brasileiros estariam usurpando o espaço de trabalho dos italianos, que sempre foram a maioria. A existência de

${ }^{16}$ Projeto História de Vida. Fundação Pró-Memória de São Caetano do Sul. 1995. 
três famílias brasileiras e uma alemã desde a sua chegada não interferia na comunidade. Estas famílias moravam em locais distantes daquele ponto considerado central. O conflito ocorreu em duas frentes: entre os italianos e entre os italianos e os brasileiros. Alguns saíram feridos e até um tiro foi disparado. Apesar da resistência da comunidade, os italianos que começaram a discussão dentro da igreja foram trabalhar na Fábrica de Tijolos. O jornal A Província de São Paulo noticiou o acontecido:

\section{Noticiario.}

Desordem em S. Caetano.

Em S. Caetano houve ante-hontem (Domingo) grande barulho, cacetadas, facadas, etc., até dentro da capella.

Os colonos desavindo-se com os empregados da olaria do sr. Samuel de Mesquita, travaram tremenda lucta, havendo facadas, cacetadas e tiros.

Ficaram feridos Matorelli Antonio, Marieta Rossi, Paschoal Luige e Frololi Luige.

Alguns estão feridos gravemente. ${ }^{17}$

Depois deste incidente Carmine Barile foi nomeado como inspetor de quarteirão pelo delegado de polícia do Brás. A função do inspetor era a de manter a ordem e mediar os conflitos, eram nomeados sempre homens que fossem moradores antigos da localidade.

As relações entre italianos e brasileiros foram conflituosas. Os intérpretes que eles conheceram só traduziam o que era conveniente, enganando-os. Por este motivo o vice-cônsul assumiu várias vezes o papel de intérprete. Em uma carta endereçada aos amigos e parentes datada de 1889, o colono Giacomo Garbelotto avisa das dificuldades e das atitudes dos brasileiros:

o desejo de vir para cá necessita de algumas informações, porque quando chegamos na Imigração em São Paulo é preciso que você veja como eles fazem. São muitos italianos mandados pelos senhores Brasileiros, estes cuidam de um tanto de (pessoas de uma) família. Estes interpretes fazem como o condutor com os animais. Um que promete uma coisa e outro que promete outra. ${ }^{18}$ (Franzina, 1979)

\footnotetext{
17 A Provincia de São Paulo. 20/setembro/1887.

18 " il desidero di venire qui che i fosse bene informati, perché quando rivano qui
} 
Os incidentes desde a chegada ao país eram reforçados pelas dificuldades de comunicação, que poderiam ser sanados, em parte, pelo aprendizado da língua. Esta possibilidade evitaria a ação de alguns brasileiros que faziam promessas e não cumpriam. Neste caso, $\mathrm{o}$ colono referia-se aos intérpretes, aos funcionários do antigo escritório da Imigração, aos comerciantes e a outras pessoas que não deveriam ser necessariamente brasileiras - poderiam ser portuguesas, espanholas ou de qualquer outra nacionalidade. A desilusão deste colono fez com que ele voltasse para a Itália e deixasse seus filhos aqui. Giacomo Garbelotto foi um dos imigrantes do grupo de 1877, um dos primeiros a chegar em São Caetano. Estava no Brasil havia 12 anos.

Nesta carta o colono lamenta a morte de crianças, filhos de seus amigos que estavam no núcleo, reclama das muitas doenças, do preço dos alimentos e diz que a alimentação inadequada poderia ser uma das causas dos falecimentos. Os imigrantes imaginavam que iriam encontrar o paraíso e quando chegavam não foi o que encontraram, não foram nem tão bem tratados. Narra Angelo Trento:

os agentes de imigração, cujo comportamento não era, para sermos clementes, totalmente honesto, (...) passam pelas aldeias nos dias de feira ou mercado, pintam o Brasil, e, sobretudo, São Paulo, como o país das maravilhas, em que o ganho é assegurado e a propriedade da terra está ao alcance da mão. É contra eles que boa parte da imprensa da época dispara seus dardos, não hesitando a compará-los com os traficantes de escravos.(Trento, 1989, p.27-29)

O colono Giacomo Garbelotto sentiu-se como parte de uma boiada.

somos conduzidos até o lugar durante oito horas de trem, mais ou menos, passamos por bosques e desertos. Colocamnos lá como ovelhas, em uma casa com quatro paredes e com o chão coberto de terra. Porque os brasileiros tem o hábito de dormir no chão, sobre uma pele de boi. O intér-

in emmigrazione a San Paulo bisogna che tu vedi come fanno: Sono tanti italiani che sono mandati dai signori Bresiliesi, e i vadagna un tanto per famiglia. Questi interpreti fanno come i senseri di la di bestie; uno ghe promete una cosa e l'altro promette l'altra." 
prete que o conduziu até o local foge ou, nós o matamos, porque eles prometem uma coisa e depois é outra. ${ }^{19}$ (Franzina, 1979)

Lendo esta carta nenhum outro imigrante teria coragem de vir para o Brasil - a não ser que as condições de vida no seu país estivessem piores.

No ano de 1890 foi fundada a Fábrica de Formicida Paulista e comprada a pequena Fábrica de Bebidas Alcoólicas e de Refinação de Açúcar pelo Banco União de São Paulo. Este Banco passou a adquirir lotes ao longo da ferrovia, prevendo o escoamento das mercadorias das fábricas que ali poderiam instalar-se, como já ocorria em outras localidades.

Com o crescimento econômico e a expansão da área inicial estabelecida para o núcleo, a necessidade de aprender a língua portuguesa foi aumentando. A participação do vice-cônsul da Itália em São Paulo tornava-se imprescindível em quase todos os negócios que envolvessem italianos e brasileiros. Apenas o colono Emílio Rossi tinha a fluência na língua nacional e era o representante dos moradores. Os colonos conseguiram aulas particulares de português nesta época.

Em 1890 foram criadas quatro olarias de propriedade de italianos. Neste ano, houve muitos protestos dos moradores porque os impostos foram cobrados duas vezes. A confusão foi originada pela instalação da Intendência Municipal de São Bernardo, no dia 12 de maio. A nova intendência enviou cobradores aos seus bairros, entre eles São Caetano, que por sua vez já havia feito o pagamento para a cidade de São Paulo. Segundo um documento do Paço da Intendência Municipal de São Paulo, esclarecendo o ocorrido, a localidade deveria pagar seus impostos para a Capital:

São Caetano sempre esteve e ainda esta em suas relações policiaes debaixo da jurisdição do Subdelegado do Braz. Seus moradores sempre foram parochiados pelo vigario do Braz e não de S. Bernardo. Todas as suas relações commer-

19 "ocore vanno a condurli al posto chi otto ore de treno e piú e meno, dentro per questi boschi o deserti e li mettono la come pieghore te una casa su quattro pali e poi smaltà di tera perché i bresilesi hanno costume di dormire in tera su una pelle di bue e la quando l'interprete al ghe li condotti il fugge se no i lo amazza, perché i ghavea promesso una cosa poi le l'altra." 
ciais são com esta Capital n'aquelle relatorio a que me referi, quando se trata das divisas do Braz, dá-se como limite com S.Bernardo a estrada que de Mogy segue para Santos, estrada essa que esta muito alêm do Ribeirão dos Meninos e de toda a colonia: por isso, embora installada a villa de S.Bernardo, não teve escrupulo em mandar fazer collecta em S.Caetano, na mente e na certeza de estar usando de um direito. 20

A falta de definição dos limites causou esta dupla cobrança. A localidade apresentava um bom rendimento para ser disputada entre os dois municípios, o que é também indício de seu desenvolvimento. São Caetano passou a ser distrito fiscal de São Bernardo no ano de 1901. Até esta data os impostos eram cobrados pela cidade de São Paulo. Tornando-se um bairro de São Bernardo, ${ }^{21}$ São Caetano permaneceu nesta condição até conseguir a autonomia administrativa em 1948, quando passou a chamar-se São Caetano do Sul.

Apesar da cobrança de impostos as condições de higiene eram precárias e as doenças persistiam, por motivos como a inexistência de médicos na região. Com a fundação da Società di Mutuo Soccorso "Principe di Napoli", em novembro de 1892, tentou-se sanar estes e outros problemas.

O terreno e o prédio da associação foram doados e construídos pelos moradores. A função da Società "Principe di Napoli" era:

a concessão de diárias aos sócios que ficassem doentes, o pagamento das despesas de farmácia, o acompanhamento obrigatório do enterro dos sócios falecidos. (...) os sócios se revezavam na cabeceira dos doentes, inclusive como enfermeiros. (...) Tratava-se de um fundo mútuo de natureza previdenciária e cooperativa. A Società não corria riscos. Para ter direito a assistência, o sócio devia aguardar um certo número de meses depois de inscrito. (...) Funcionava,

20 Número de ordem 5542. Paço da Intendencia Municipal de São Paulo. 26/dezembro/1890. Enviado ao Governador do Estado. Arquivo do Estado de São Paulo. (AESP).

${ }^{21}$ Em 1938 o município de São Bernardo ou Estação de São Bernardo passou a denominar-se Santo André. A Vila de São Bernardo foi denominada de São Bernardo do Campo em 1944. 
na prática, como uma associação de seguro comunitário. (Martins, 1992, p.196)

Ela aceitava como sócios todos os homens italianos moradores da localidade e, de acordo com suas atas de reuniões, manteve durante 40 anos o italiano como língua oficial. Esta associação, apesar do crescimento da localidade, permaneceu fechada para não-italianos e suplantou as ações da Irmandade de São Caetano, que se tornou uma entidade voltada somente para as obras religiosas, rezas e quermesses.

A Società "Principe di Napoli" foi mais uma das associações fundadas por italianos a partir da década de 1890 no Brasil, seguindo os moldes das associações italianas. Estas entidades acabaram por tornar-se o elo de ligação com a terra natal e normalmente eram formados por pessoas vindas da mesma região. A denominação que recebiam eram em homenagem a reis, príncipes, poetas, cantores ou qualquer cidadão italiano considerado importante para o grupo.

Nos anos de 1898 e 1899 foi formada pelos moradores uma comissão para a reconstrução da capela. Esta comissão foi acompanhada por dois padres que moraram estes anos na localidade, um em cada ano. A igreja barroca foi demolida e teve início a construção da matriz.

Nestes anos a Fábrica de Refinação de Açúcar e de Destilação de Bebidas Alcoólicas do Banco União de São Paulo expandiu-se e um novo prédio foi construído. Os terrenos da Fábrica de Tijolos Paulista ao lado da igreja foram comprados por Pamplona, Sobrinho \& Companhia, que inauguraram a Fábrica de Sabão e Graxa - no mesmo local que a princípio deveria ser destinado para a ampliação da igreja e construção do cemitério. Este local denominado de lote reservado, como consta do traçado inicial do núcleo, era cercado pelo rios Tamanduateí e dos Meninos e pela Estrada de Ferro, que por sua vez, precisou desapropriar alguns lotes e parte deste lote reservado para a sua duplicação, reduzindo ainda mais o tamanho do terreno. Este mesmo terreno foi adquirido pelas Indústrias Reunidas Francesco Matarazzo em 1916. 


\section{Referências Bibliográficas}

ALVIM, Zuleika M. F. Brava gente! Os italianos em São Paulo 1870-1920. São Paulo: Brasiliense. 1986.

CARNEIRO, José F. D. Imigração e colonização no Brasil. Rio de Janeiro: Universidade do Brasil, 1950.

CENNI, Franco. Italianos no Brasil: andiamo in Merica. São Paulo: MartinsFontes, 1975.

FRANZINA, Emilio. Merica! Merica! Emigrazione e colonizzazione nelle lettere dei contadini veneti in America Latina. 1876-1902. Milano: Feltrinelli. 1979.

MARTINS, José de S. A formação do espaço regional do Tijucuçu e de São Caetano. Revista Raízes, São Caetano do Sul, nº 5, jul. 1991.

. Subúrbio. Vida cotidiana e história no subúrbio da cidade de São

Paulo: São Caetano, do fim do Império ao fim da República Velha. São Paulo: Hucitec/PMSCS, 1992. . A escravidão em São Caetano 1598-1871. São Caetano do Sul:

A. L.Gama/STICMSCS/Cedi, 1988.

. Prefácio. In: José V. T. dos Santos. Colonos do vinho: estudo sobre a subordinação do trabalho camponês ao capital. São Paulo: Hucitec, 1978 PINTO, Adolpho A. História da viação pública de São Paulo. 2 ed. São Paulo: Governo do Estado de São Paulo. Coleção Paulística. v. I, 1977.

PIRATININGA JÚNIOR, Luiz G. Dietário dos escravos de São Bento: originários de São Caetano e São Bernardo. São Paulo: Hucitec/PMSCS, 1991.

TRENTO, Angelo. Do outro lado do Atlântico: um século de imigração italiana no Brasil. Tradutor: Luiz E. de L. Brandão. São Paulo: Nobel, 1989.

VERONA, Antonio F. Pacto social e luta operária em Schio. Revista Brasileira de História. São Paulo: Anpuh/Humanitas Publicações, n 34, 1997. 